\title{
Analysis of the trajectory of the Brazilian Nursing Association - Ceará Section
}

\author{
Análise da trajetória da Associação Brasileira de Enfermagem - Seção Ceará
}

André Ribeiro de Castro Júnior ${ }^{1}$, Silvia Maria Nobrega-Therrien ${ }^{1}$, Maria Irismar de Almeida ${ }^{1}$, Daniele Vasconcelos Fernandes Vieira ${ }^{1}$, Francisca Gomes Montesuma ${ }^{1}$

Objective: to describe the trajectory of the Brazilian Nursing Association. Methods: documental research with data obtained mainly from minutes of meetings of the Brazilian Nursing Association - Ceará Section. A book report was produced, with quantitative and qualitative surveys of recurrent terms and issues in the minutes. Data were triangulated and interpreted into categories. Results: information concerning the association were divided into five categories, which exposed the profile of the boards and their priorities in the nursing discussion in Ceará, highlighting challenges, struggles and positions about nursing education, and encouraging the production and scientific dissemination, contextualized in the social and political conditions. Conclusion: the Brazilian Nursing Association - Ceará Section is emblematic in building the history of the profession in Ceará, because it brings reflections about the importance of associations to strengthen and bring visibility to the class struggles, the qualification of education and the expansion of scientific production.

Descriptors: Nursing; History of Nursing; Education, Nursing.

Objetivo: descrever a trajetória da Associação Brasileira de Enfermagem. Métodos: pesquisa documental com dados obtidos principalmente das atas de reuniões da Associação Brasileira de Enfermagem - Seção Ceará. Produziu-se fichamento, com levantamento quantitativo e qualitativo de termos e assuntos recorrentes nas atas. Os dados foram triangulados e interpretados em categorias. Resultados: as informações referentes à associação foram divididas em cinco categorias, que expuseram o perfil das diretorias e suas prioridades na discussão da enfermagem cearense, destacando desafios quanto a lutas e posicionamentos sobre o ensino da enfermagem, e ao estímulo à produção e divulgação científica, contextualizadas nas condições sociais e políticas. Conclusão: a Associação Brasileira de Enfermagem - Seção Ceará é emblemática na construção da história da profissão no Ceará, ao ativar reflexões sobre a importância do associativismo no fortalecimento e na visibilidade das lutas de classe, a qualificação do ensino e a ampliação da produção científica.

Descritores: Enfermagem; História da Enfermagem; Educação em Enfermagem.

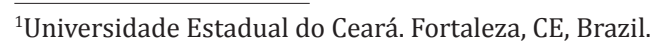




\section{Introduction}

The Brazilian Nursing Association has its importance in scientific production, through conferences, symposia, seminars and conferences, as well as other social events, which provide to its members, besides socio-cultural and political empowerment, benefits such as the expansion of dialogues about education and work in nursing ${ }^{(1-2)}$.

In its history of struggles for democracy, ethics and commitment to Brazilian nursing, the association levers actions in defense of life and training of professionals committed to the population's quality of life, social justice and the guarantee of citizenship ${ }^{(3-4)}$.

Over time, there is growing broader participation of the Brazilian Nursing Association in promoting scientific and professional development, making it increasingly known and recognized by national and international government, social control and nursing authorities $^{(5)}$.

The conditions and the impacts of associations in social life can be analyzed in several ways, following different objectives and analytical approaches in order to evaluate the influence of groups and associations in the socialization process of individuals; the potential to promote reproduction, integration and social transformation; their ability to leverage economic development; fostering belonging structures and cultural identity, among others. Inserted in the field of political sociology, this article is justified because it investigates the relationship between associations and democracy, having as a background the contemporary societies marked by a high degree of complexity and plurality of social life $\mathrm{e}^{(6)}$.

Among other contributions, associations allow larger areas of democratic practices in various spheres of social life, providing an alternative way to give greater visibility to a group of disadvantaged individuals in society or who still struggle for unreached inte- rests. In the case of nursing, the moviment promoted by the association becomes clearly an instrument of struggle for its recognition as a profession not only in the state of Ceará, but also in Brazil and in the world ${ }^{(7)}$.

The Brazilian Nursing Association - Ceará Section is an institution that, since its creation, through this partnership model, seeks to strengthen the relationship in a professional class that can be defined as a social practice that promotes certain management group involved by large and particular objectives grounded in a common focus. In parts, the main focus the association movement succeeded in promoting interventions that establish a link among members, encouraging discussions and reflections on the future of nursing, which were made possible by the union established between those professionals because of the historical difficulties experienced by the nursing staff $^{(8-9)}$.

The professional status is defined as social prestige, derived from the belief that society has that the occupation has such attributes, and the belief in the dignity and importance of their job. This recognition is also expressed by the organized political power and recognized in society, when designing the association as representative of the category. This combination should be perceived by its members as a common variable to these members, but considered particular in relation to the social whole and to the government $^{(10-11)}$.

This research arises from the understanding of the importance of this association for the profession in general and in the State of Ceará, being perceived as a collective representative in the struggle for recognition and rights of nursing professionals. One should also understand the relevance of a class organization (nurses, nursing technicians and nursing students), to defend common interests. The participation in health associations, especially nursing ones, seeks to promote the activities of individuals participating in the 
social field and, thus, it provides own values of a civic culture. This factor tends to strengthen democracy and social ties.

The relevance of research documenting the history and the memory of this association in the state of Ceará, given the lack of research on the topic, highlights the need to give visibility to its historical nature of work. The study of association movements in the Brazilian Nursing Association - Ceará section can show nurses' political and social relevance in this partnership model, as well as contribute to the understanding of the bonding process in the institution and strengthening of this institution, to strengthen ties between professionals and society.

Even though it has an important representation, it seems that the Brazilian Nursing Association - Section Ceará has silenced its history due to the lack of publications and reports of its history. So, this is a pioneering research regarding the preservation of the institution's history, finding as a difficulty in the outline of the research the lack of publications about the institution, having to resort to less recent materials such as the intention to rescue data from the Brazilian Nursing Association - Ceará Section and its association model.

This research aims to describe the trajectory of the Brazilian Nursing Association 0 Ceará Section.

\section{Methods}

A documental type study was conducted. In the positivist conception of history, the document is something objective, neutral, and that serves to che$\mathrm{ck}$ facts and events in a linear perspective. The idea of document as a monument, which appeared in the New History, is opposed to this understanding, postulating that every historical source expresses the power of a past society about memory and future. Thus it requires another focus of analysis of the document that takes into account the reconstruction of a fact into a problematical and, above all, understanding point of view - not only informative and explanatory. With this view, original documents were dealt with, belonging to the Brazilian Nursing Association - Ceará Section still free from analytic treatment, as well as the minutes of the association's board meetings ${ }^{(12)}$.

Data collection occurred in the institution headquarters from June 2015 to May 2016. One sought the history of the institution in the 2003-2013 period, setting a decade of records for analysis. The time frame is justified because it represents the longest term of a president of the Brazilian Nursing Association Ceará Section.

In the documental sources, one collected primarily information about the boards, their accomplishments, milestones, challenges, struggles and achievements, characterizing the types of records made during meetings. There was, at first, the reading of ten minutes and thereafter ledgers were consulted and also sent and received official documents. In the second step, one produced a book report, with quantitative and qualitative terms and subjects recurrent in the minutes. In a third step, the data were triangulated and interpreted into categories and subcategories in order to systematize the textual content of the minutes, ledgers and official documents of the Brazilian Nursing Association - Ceará Section.

\section{Results}

The content of the minutes showed what members of the association thought or what they did about the teaching of the profession. One found names that represented nursing in Ceará, emphasizing, as the construction of associative practice, the joints made in the name of better social and political conditions for nursing in that period (Figure 1). 


\begin{tabular}{|c|c|}
\hline 2003 a 2006 & 2007 a 2013 \\
\hline \multicolumn{2}{|c|}{ Category 1: Knowledge about teaching of the profession } \\
\hline $\begin{array}{l}\text { 1.1 Information about the laws of nursing teaching } \\
\text { 1.2. Knowledge about the project of creation of nursing schools }\end{array}$ & $\begin{array}{l}\text { 1.1. Training of nurses and students for research initiation } \\
\text { 1.2. Dissemination of channels of scientific publications }\end{array}$ \\
\hline \multicolumn{2}{|c|}{ Category 2: Opinions about the teaching of the profession } \\
\hline $\begin{array}{l}\text { 2.1. Critical attitude towards the conditions of establishment of } \\
\text { nursing schools in the local community }\end{array}$ & $\begin{array}{l}\text { 2.1. Technical training courses for professionals and nursing } \\
\text { students }\end{array}$ \\
\hline \multicolumn{2}{|c|}{ Category 3: Feelings regarding the teaching of the profession } \\
\hline \multicolumn{2}{|l|}{ 3.1. Autonomy regarding the process of training of nursing teaching } \\
\hline \multicolumn{2}{|c|}{ Category 4: Opinions about the political struggles of the Brazilian Nursing Association - CE } \\
\hline $\begin{array}{l}\text { 4.1. Knowledge about the Brazilian Nursing Association - CE } \\
\text { 4.2. The popularity of the profession in the society }\end{array}$ & 4.1. Nursing representation on health associations \\
\hline \multicolumn{2}{|c|}{ Category 5: Opinion about religious manifestations and homage } \\
\hline 5.1. Proximity between faith and the profession & $\begin{array}{l}\text { 5.1 Tributes to former presidents of the Brazilian Nursing } \\
\text { Association - CE and to retired nurses }\end{array}$ \\
\hline
\end{tabular}

Figure 1 - Systematization of the textual content of the minutes of the Brazilian Nursing Association - Ceará Section

\section{Discussion}

The ownership of the Brazilian Nursing Association, from the point of view of the historical construction of nursing in Ceará shows the important role of associations, highlighting the institution as a representative of the interests of the profession, and bringing together nurses, technicians, assistants and nursing students. The historical design enables the knowledge of its achievements as well as challenges to be overcome. The designed profile brings, however, limitations such as the scarcity of material about the institution, presenting gaps in primary sources, as to the specific decisions and outstanding shares in the temporal clippings, as well as in relation to the detailed analysis of the impacts of these moments in current situation of nursing in the state of Ceará.

Category one: Knowledge about the teaching of the profession shows the knowledge of the members of the Brazilian Nursing Association - Ceará Section about the teaching of the profession. In the minutes of the period from 2003 to 2006, two sub categories were systematized, "information about the nursing education legislation" and "knowledge about the project for the creation of nursing schools."
Based on the most frequent context units of the first group of minutes, it was inferred that the contents of this category reveal, by the speaches of its board members, reports about the representations of association members in relation to the teaching of the profession, both concerning information about the laws of high school, as well as the knowledge about the project to create a nursing college in the reality of Ceará.

Concerning the years between the period 2007 to 2013, there is the division of minutes with focus on "training of nurses and students to start research" and "dissemination of scientific publications channels." The theme "research" was identified as part of the struggles of the Brazilian Nursing Association - Ceará Section. Its members were concerned about the relevance of this issue, as this issue was addressed by the board of directors. The focus was on events to publicize the characteristic of nursing knowledge by the association, to promote events, disseminate nursing knowledge and allow initiation and training for research through training courses.

Changes in the profile of a professional category accompany demands of social, cultural, political and scientific characteristic, in which individuals are involved. When developing the teaching and the nur- 
sing profession, there is the exchange of the teaching model, which has a more informative characteristic. The seek for a researcher nursing highlights the need for education to appropriate itself of nursing scientific knowledge. Interest in research therefore becomes an influencer for the dissemination of this knowledge, not only for the self-knowledge of the category, but also for the recognition of society that it attends - it is worth mentioning the Brazilian Nursing Association - Ceará Section as a vehicle in the propagation of nursing science ${ }^{(6,13-14)}$.

Regarding Category 2: Opinions about the teaching of the profession, the discussions are organized into two subcategories: "critical attitude towards the conditions of creation of nursing schools in the local community" (2003-2006) and "courses of technical training for professionals and nursing students" (2007-2013).

The first subcategory reveals an opinion related to compliance with the legal aspects of training of nursing professionals, dedicated to undergraduate education. The creation of the course project at this level was under the responsibility of the nursing category; back in the day this education was a medical liability. Then, there was the empowerment of nursing due to its teaching and its autonomy as a profession. Wits positive positions, responsibilities are shared among professional nurses.

The second category gathers context units that refer to the concerns and opinions of nurses about technical training courses for professionals. There is an adaptation of members and institutions to the "technical model" currently required, as the search for scientific knowledge requires the improvement of the knowledge acquired in the profession. Such evidence strengthens the claim that the social representations of the members of the Brazilian Nursing Association - Ceará Section guided their behaviors for the training responsibilities of professionals of the area and of its own members.

The feelings about the teaching of the profession reveal that the members of the Brazilian Nursing
Association - Ceará Section indicate that there is a unit in the process of nursing education in the state of Ceará, emerging, from this analysis of the feeling expressed, the subcategory that deals with "autonomy regarding the process of nursing education."

The partners, together with the institution, having a wish to change the nursing education situation, which has its base side founded in the biomedical knowledge, promote events, courses and meetings to promote cultural capital, develop the feeling of belonging to the institution and create zones of influence. Thus, they are the associative life catalysts, so that nurses' professional training start to have its autonomy dedicated to nursing knowledge - different from the older teaching model, in which various nursing schools emerged with a knowledge field limited to the biomedical model, often having most of its faculty formed by doctors.

The need for changes in the education of nurses and nursing technicians, also in the processes of recognition of the profession, is a banner of struggle with which the Brazilian Nursing Association - Ceará Section consolidates in this study period, having achievements recognized by peers. Since the late 1980s until now, this fight has been strengthened by a number of events in the context of the Brazilian society and in health education - specifically nursing. Teaching is influenced by changes in the social perspective (as in the case of the Health Reform and the implementation of the Unified Health System) and it aims at fitting to less technical models, more human-centered and focused on individuals. Nursing, beyond this biomedical model, needs visibility and its own scientific knowledge ${ }^{(6-14)}$.

The subcategories "knowledge about the struggles of the Brazilian Nursing Association-CE" and "propagation of the profession in the society" refers to the desire of the institution to spread knowledge of the profession. To do so, in the early 21st century one implemented the Participation Movement of the Brazilian Nursing Association at national level and consequently at local level. This movement presented 
a more participative association in movements that fight for ideals in favor of nursing, becoming more visible to society and stronger as a political representative. Although with a reduced number of partners, these struggles and the spread of nursing guided by scientific knowledge have always been the goal of the Brazilian Nursing Association - Ceará Section.

Regarding the subcategory "representation of nursing in health associations", one found out that even though it was silenced, regarding its number of members, the institution has large participation in movements and struggles that defend the category .

It is exactly through these autonomous, diffuse and formal characteristics that are grounded the foundations for its influence on democracy, denouncing injustice and questioning the traditional relations of social power and representation. This freedom of association is fundamental, from the democratic point of view, because it establishes that a diversity of interests, opinions and perspectives should have its aspects represented in the public sphere. In general, such perspectives defend that associations contribute to the promotion of good citizens; strengthen collective bonds based on trust, cooperation and public spirit; They represent groups and vulnerable and excluded sectors; publicize demands and social problems; and promote co-management and occupy spaces of public policies, enriching the foundation of participation and political representation in contemporary democracies ${ }^{(15)}$.

However, it is necessary to advance in the understanding of the relationship between the associative practices and the health field, particularly in nursing. One must analyze the current democratic effectiveness of these practices in subjects, either in the individual level, or in the political and/or social level, taking into account the numerical representation, regard the members of the institution.

Category 5: Opinion about religious manifestations and homages gathers the context units referring to the attitudes of the group of nurses from the Brazilian Nursing Association - Ceará Section related to the cult of the Catholic religion in the period from 2003 to 2006. Although in this period, there was not so much religious influence, it existed, even because of the origin with Sister Cecília Fernandes Pequena, revealing a connection with the sisters of charity from Escola São Vicente de Paulo in its origin.

In the second period of grouping of the minutes, one systematized the opinions of the members of the Brazilian Nursing Association - Ceará Section in relation to the homages paid to former presidents. There was the inauguration of the photographic panel of former presidents, an action that represents a valuation of the history of the institution and recognition of the work of renowned professionals that worked in the association.

The identity of social subjects, which were once built on cultural factors of class, gender and even of religious aspect, underwent transformations. This change is more visible after the late $20^{\text {th }}$ century, and it opens new possibilities of social representation. This change is characterized by a high level of search for social support. It can be identified the loss of a cultural trait, but also the gain of a more rational and scientific professional bond. Such decoupling is presented since the very notion of need for professional growth ${ }^{(6-15)}$.

The representational content learned by the analysis of the minutes was indispensable in the process of understanding the knowledge and opinions of the members of the Brazilian Nursing Association - Ceará Section. This allowed one to know how the work of this associaton was developed by the boards during the period studied. Due to the gaps in publications that register the history of this association, one highlights the importance of this study, which rescued data about it and its association model, its struggles and achievements for the consolidation of nursing in the current scenario. 


\section{Conclusion}

The history of the Brazilian Nursing Association - Ceará Section showed concerns, struggles and achievements, considering the political and social conjuncture of the time, triggering reflections on the importance of associations and triggering a discussion about how this profession is seen today. The class struggles have been recognized as essential for the qualification of education, the expansion of scientific production and the appreciation of the profession, in the social dimension and in the construction of policies.

\section{Collaborations}

Castro Júnior AR and Nobrega-Therrien SM contributed to the project design, organization and interpretation of data, article writing and final approval of the version to be published. Almeida MI, Vieira DVF and Montezuma FG contributed to the critical review of the intellectual content.

\section{References}

1. Moreira MC. Dimensões do associativismo voluntário no cenário das relações entre saúde, pobreza e doença. Ciênc Saúde Coletiva [Internet]. 2010 [citado2017mai.8];15(3):917-24.Disponível em: http://www.scielo.br/scielo.php?script=sci arttext\&pid=S1413-81232010000300035

2. Silva FV. Caminhos percorridos pela ABEn no período de 2004 a 2007 [editorial]. Rev Bras Enferm [Internet]. 2007 [citado 2017 mai. 8]; 60(6):617. Disponível em: http://www.scielo.br/ pdf/reben/v50n3/v50n3a01.pdf

3. Silva KL, Sena RR, Grillo MJ, Horta NC. Formação do enfermeiro: desafios para a promoção da saúde. Esc Anna Nery [Internet]. 2010 [citado 2017 mai. 8]; 14(2):368-76. Disponível em: http://www. scielo.br/pdf/ean/v14n2/21.pdf
4. Santana MN. O desafio de representar a ABEn no Conselho Nacional de Saúde [editorial]. Rev Bras Enferm [Internet]. 2004 [citado 2017 mai. 8]; 57(4):393. Disponível em: http://www.scielo.br/scielo.php?script=sci arttext\&pid=S0034-71672004000400001

5. Vale EG, Fernandes JD. Ensino de Graduação em Enfermagem: a contribuição da Associação Brasileira de Enfermagem. Rev Bras Enferm [Internet]. 2006 [citado 2017 mai. 8]; 59(esp):41722. Disponível em: http://www.scielo.br/pdf/ reben/v59nspe/v59nspea06.pdf

6. Associação Brasileira de Enfermagem (ABEn). Centro de Estudos e Pesquisa em Enfermagem. Histórico. Apresentação [Internet]. 2015 [citado 2017 mai. 8]. Disponível em: http://www. abennacional.org.br/home/historico.htm

7. Leal S, Vargas ER. Entre associativismo e regimes de engajamento: reflexões acerca do conceito de inovação social para pensar políticas públicas de inovação. Estud Sociol [Internet]. 2014 [citado 2017 mai. 8]; 19(37):349-69. Disponível em:http://www.coppead.ufrj.br/upload/ publicacoes/lealevargas.pdf

8. Cabral IE, Almeida Filho AJ. 85 anos de ABEn® e 80 de REBEn ${ }^{\circledR}$ promovendo o desenvolvimento científico e profissional da Enfermagem brasileira. Rev Bras Enferm [Internet]. 2013 [citado 2017 mai. 8]; 66(spe):13-23. Disponível em: http:// www.scielo.br/pdf/reben/v66nspe/v66nspea02. pdf

9. Tesser Júnior ZC, Ribeiro J, Domingos FL, Bett JV, Lopes VF, Manenti FM, et al. O papel do associativismo político na promoção de saúde. Saude Transf Soc. 2015; 6(3):1-8.

10. Bellaguarda ML, Padilha MI, Peres MA, Paim L. Enfermagem profissão: seu status, eis a questão. Rev Enferm UERJ [Internet]. 2016 [citado 2017 mai. 8]; 24(2):91-5. Disponível em: http://www. facenf.uerj.br/v24n2/v24n2a08.pdf

11. Luchmann LH. Abordagens teóricas sobre o associativismo e seus efeitos democráticos. Rev Bras Ci Soc [Internet]. 2014 [citado 2017 mai. 8]; 29(85):159-78. Disponível em: http://www. scielo.br/pdf/rbcsoc/v29n85/11.pdf 
12. Associação Brasileira de Enfermagem - Seção Ceará. Histórico [Internet]. 2014 [citado 2017 mai. 8]. Disponível em: http://aben-ce.com.br/ historico

13. Perez D. Análise das matrizes sobre associativismo civil norteadoras da formação de trabalhadores para Ongs. Publ UEPG Ci Soc Apl [Internet]. 2013 [citado 2017 mai. 8]; 21(1):53-71. Disponível em: https://repositorio.unesp.br/handle/11449/127048.
14. Tesser Júnior ZC, Ribeiro J, Domingos FL, Bett JV, Lopes VF, Manenti FM, et al. $\mathrm{O}$ associativismo civil e a política de saúde no Brasil. Saúde Transf Soc. 2016; 6(3):1-8.

15. Gleriano JS, Marca NC, Justi J. Perfil e significados para a formação em enfermagem. Rev Saúde Desenvolvimento. 2017; 11(6):84-101. 